\title{
Analysis of the Vocabulary Characteristics and Teaching Strategy of Business English Based on Corpus
}

\author{
Zheng Jingzhi, Wen Lin \\ Hubei University of Science and Technology, Xianning City, Hubei Province, 437005
}

Keywords: corpus, business English, vocabulary characteristics

\begin{abstract}
In recent years, business English is a relatively new discipline. And China attaches more importance to business English, so as to strengthen the research and construction of corpus in the development, which has achieved good results. The construction and use of corpus in business English helps systematize the business English and provides new approaches and convenience for disclosing the use disciplines of the business English language, the research and teaching of business English, research and development of teaching materials and teaching test. Therefore, in order to do the work well, this paper deeply analyzes the influence and application of the basic characteristics and corpus of business English vocabulary on the vocabulary teaching of business English, so as to help the business English discipline gain further development under the influence of corpus.
\end{abstract}

\section{Introduction}

Corpus is the integration of language materials and is the important material used for language research. It can not only help people study languages through the written materials, but also conduct according researches through oral language materials. With the progress and development of the times, the corpus mainly deals with and stores it through the computer information technology, which is helpful to provide a new means and method for linguists to conduct language research through setting up corpus. It will help people further see the nature of language through phenomenon in the further development, so as to avoid researches' being influenced by subjectivity and one-sidedness in the research process and influence their efficiency in the process of language research. Therefore, with the improvement of domestic technical levels, the research of corpus has gradually become a main mode of language research. Through this mode, the work including the collection of language text, preservation of language materials and arrangement of language materials can be done, so as to further combine the corpus and language teaching, make the corpus help with the class teaching and further improve the use efficiency of the corpus.

\section{Basic Characteristics of Business English Vocabulary}

Generally in the process of international commerce activities, when the countries conduct the negotiations of business trade, they will use the most accurate and clearest business English to communicate and exchange with bosses and clients in order to guarantee the communication efficiency of both sides. Through this mode, it will not only help improve the communication efficiency, but also guarantee the success of the commercial activities. Therefore, to use the business English is of great promoting role in carrying out the commercial activities. Compared with the common English vocabulary, the business English vocabulary owns its own unique characteristics in the process of use, which is also a huge obstacle for most of the people to learn the business English well. Therefore, in order to conduct successful and effective communications in the business activities, we need to fully understand the basic characteristics of business English vocabulary.

\subsection{Application of Business Meanings of Common Vocabulary}

Language is formed in people’s constant exchanges and development, which is a phenomenon 
exclusive to the human society. Therefore, the language will develop with the constant changes of the society in the development process and further reflect the social development in the changes of vocabulary. Generally, if the common vocabulary wants to embody the professionalized characteristics in terms of business, the conversion of part of speech and extension of word meaning will be conducted to turn the common vocabulary into the semi-professionalized vocabulary in the use process, which is helpful for the business partners to have a good impression in the process of listening to words [1]. The common meaning of clearing is to eliminate and purify, but it is changed to "exchange of bill" in the business. Although the two seem unrelated, yet the use of it in the process of business negotiations will make you professional, which is helpful for improving the negotiation effects. Meanwhile, with the progress and development of the times, the past old vocabularies will have new meanings with the development of the times. And the same word will have different meanings out of the influence of many factors in the different business orientation, different business environment and the allocation with different vocabularies.

\subsection{Frequently Used Abbreviations}

When people from different countries and regions conduct business activities, in order to guarantee the efficiency of business negotiations, they not only use the business English to conduct the negotiation activities, but also use more abbreviations to conduct related activities. In the use process, the abbreviations are characterized by the concise language, convenient use and large amount of information, so they are easily loved by multiple people in the process of business activities, so as to further improve the quality of business negotiations [2]. Generally, the abbreviations are shown to people through three different forms. First of all, in the process of telecommunications and telex of international trade, in order to make the related staff have sufficient understanding of the activities, the abbreviations will be applied. For example, the English of balance of sheet is balance of sheet; however, in order to improve the negotiation efficiency of both parties, generally the abbreviation B/S will be used. Second, there are international trade organizations of multiple forms in the world. Therefore, in order to make distinctions among these organizations, people will make distinctions of the names of the organizations through abbreviation, so as to promote the communication efficiency. For example, the English name of World Trade Organization is World Trade Organization, but in order to facilitate people's understanding and memory, the abbreviation of WTO is generally used to replace it. Third, Cash on Delivery, Document against Acceptance, Uniform Customs and Practice for Documentary Creditsare all the common vocabularies in business English. However, some of the vocabularies have over-long English names, their abbreviations are often used, such as COD, D/A, UCPDC, which is favorable for the smooth implementation of the business activities.

\section{Influence of Corpus on the Teaching of Business English Vocabulary}

With the progress and development of the times, there are more and more language materials stored in the corpus and the quality is also improved, so that people have a wider and wider application of the corpus in the process of language teaching, which also has important influence on the development of the teaching of business English vocabulary.

\subsection{Help Further Improve Students Learning Effects}

The development of corpus changes the teaching contents of teachers. The corpus has abundant vocabularies and has multiple explanations in terms of vocabulary use, so when teachers teach the word use to students, they can use the large amount of information in the corpus to further enrich their teaching contents in order to make students have full understanding of the knowledge, which helps teachers better master the key points of teaching in the teaching process and promotes students' learning initiative [3]. And when the corpus of business English guides the teachers and students for the class teaching and post-class research, it also helps them gain more convenience in related learning activities; it also helps improve students' learning effect. Students can inquire the corpus software through the multimedia language learning room, so as to learn more real corpus and 
further help students find the disciplines of a certain language phenomenon from the abundant corpus and help students master more information and perfect their language knowledge in the learning process, which helps with the further development of students.

\subsection{Hels Students Do the Work of Learning Test}

In the learning process of business English vocabulary through the corpus, students can also test their language through the strong function of language test, so as to further improve teachers' objectiveness and effectiveness of teachers' teaching evaluation system, which is favorable for the further development of students' learning. In conducting the teaching evaluation, teachers can find the materials required by the test through the corpus. The objectiveness and practicality of a large number of test types in the test bank closely combine the test contents and teaching contents, thus guaranteeing the effectiveness of tests and the test quality of students [4]. At present, the international community owns English exams of multiple forms, such as TOFEL, GRE and GMAT. In order to guarantee the equality of these exams, the corpus is applied to the exams. The language materials stored in the corpus not only have the advantage of quantity, but also promote the quality improvement of the language materials, which helps students further do the learning test. The corpus can not only choose the test materials in the business English test, but also choose the test options. Through this mode, it helps avoid the influence of the subjective factors in the test process, further improve the standardization of the test and further do the feedback and evaluation work after exams.

\section{Application of Corpus to the Teaching of Business English Vocabulary}

\subsection{Study the Collocation}

Collocation refers to the neighboring works with the high co-occurrence connections or combinations. It is also the junction of grammar and vocabulary; it is the most active research field in the research of corpus linguistics [5]. Generally, the collocation appears through three forms: free combination, limited combination and idiom. And in the English vocabulary, "make", as a verb, can be combined with various words, such as make movie, make toys, make a plan, make a mistake, make a friend; it has the strong combination ability and belongs to the free combination. The verb "pose" can only have the four collocations: "pose a problem, pose a dilemma, pose a threat and pose a danger"; it has the limited collocation scope and belongs to the limited combination. And the combination structures like "kick the bucket, make a scene" are relatively fixed, which belong to idioms. In general cases, most of the English vocabularies are in the form of free combination; there are less limited combinations and idioms. Therefore, in the process of learning through corpus, students can learn the vocabularies of free combinations, which helps improve their learning efficiency.

\subsection{Master the Key Points and Difficult Points of Business English through Corpus}

In the teaching of vocabulary, if teachers totally neglect the context teaching of the vocabulary English and the teaching of polysemy, students cannot master more comprehensive business vocabularies in the learning process. Therefore, in order to improve students' vocabulary, teachers have to teach the business English through the corpus. Generally, people tend to use the public vocabularies in the business activities. Therefore, if teachers use the corpus to teach the business English vocabularies, it helps the teachers and students make statistics of the application frequency of the vocabulary, so as to further determine the application frequency of the English vocabulary and make them proficiently master and apply the vocabularies. Through this mode, it can help students improve the learning efficiency and trigger students' learning initiative. It helps teachers improve the teaching effects to a certain degree.

\subsection{Have a More Understanding of the Vocabulary Collocation of Business English}

Generally, most of the languages in the corpse should be applied in the real concrete scenes. Therefore, in the teaching process, teachers must guarantee the realness and objectiveness of the 
corpus. Then they guide students to learn related example sentences through this mode, which helps students know about some commonly used fixed collocations in various business activities, so as to further improve their understanding of business English and improve their scores of business English.

\section{Conclusions}

All in all, business English, as the English of a special nature, helps students improve their actual interpersonal ability in the concrete business environment through the learning of business English. Meanwhile, it also greatly promotes students' ability of thinking and distinguishing ability. Therefore, in order to promote students' further development, teachers need to introduce the corpus into teaching in the teaching process, so as to provide students with the more real English learning platform and keep improving students’ language expression and actual application ability.

\section{References}

[1] Zou Li. Learning and Exploration of Business English Vocabulary Based on Corpus [J]. Teacher Method Research, 2013, 30(3):143-145.

[2] Zhou Miaomiao. Research of Business English Vocabulary Characteristics of Vocational Universities Based on Corpus [J]. Youth Literator, 2014, 6(1):141.

[3] Liu Li. Characteristics of Business English Vocabulary and Memory Strategy [J]. Journal of Chuzhou University, 2012, 8(4):51-52.

[4] Xu Xia. Characteristics of Business English Vocabulary and Chinese Translation Skills [J]. Business Perspective, 2011, 14(35):45-46.

[5] He Xia. Characteristics of Business English Vocabulary and Initial Exploration of Chinese Translation [J]. Overseas English (Mid Periodical), 2011, 18(11):56. 